\title{
Pengembangan Perangkat Pembelajaran IPA Model Inkuiri Terbimbing Berbasis Multiple Intelligences untuk Melatihkan Keterampilan Proses Sains Peserta Didik SMP
}

\author{
Hairunisa ${ }^{1}$, Arif Rahman Hakim ${ }^{2}$ \\ ${ }^{1,2}$ STKIP Taman Siswa Bima \\ 1anis010286@gmail.com
}

\begin{abstract}
ABSTRAK
Penelitian ini bertujuan untuk menghasilkan perangkat pembelajaran IPA berbasis inkuiri terbimbing berdasarkan teori multiple intelligences yang layak untuk melatihkan keterampilan proses sains peserta didik SMP. Perangkat pembelajaran diujicobakan pada kelas VIII dengan rancangan one group pretestposttest design, sedangkan analisis data secara deskriptif kuantitatif kualitatif. Hasil validasi perangkat pembelajaran menunjukkan perangkat pembelajaran, meliputi: (1) RPP; LKP; Buku Ajar; dan instrumen penilaian keterampilan proses sains. RPP terlaksana dengan baik, dan peserta didik memberi respon positif terhadap pembelajaran. Tes keterampilan proses sains pada keterampilan abstrak dianalisis dengan n-gain 0.60 dengan kategori sedang dan pada keterampilan konkrit dianalisis dengan rata-rata 3.6 dengan kategori A-. Kesimpulan dari penelitian ini yakni perangkat pembelajaran berbasis inkuiri terbimbing berdasarkan teori multiple intelligences yang dikembangkan memenuhi syarat validitas, kepraktisan, dan efektivitas sehingga layak diimplementasikan dan dapat melatihkan keterampilan proses sains peserta didik.
\end{abstract}

Kata kunci: Inkuiri Terbimbing, Multiple Intelligences, Keterampilan Proses Sains.

\section{PENDAHULUAN}

IPA merupakan kombinasi dua unsur utama, yaitu proses dan produk yang tidak terpisahkan. IPA sebagai proses meliputi keterampilan proses dan sikap ilmiah yang diperlukan untuk memperoleh dan mengembangkan pengatahuan, sedangkan sains sebagai produk berupa kumpulan pengetahuan yang meliputi fakta, konsep, generalisasi, prinsip, teori dan hukum.

Produk IPA diperoleh melalui suatu proses berpikir dan bertindak dalam menghadapi atau merespon masalah-masalah yang ada di lingkungan, yang kemudian dikenal sebagai proses ilmiah. Sejumlah proses IPA yang dikembangkan para ilmuwan dalam mencari pengetahuan dan kebenaran ilmiah itulah yang kemudian disebut sebagai keterampilan proses sains. Berbagai sumber yang dirujuk Zubaidah, dkk (2013a, 2013b), menyatakan bahwa keterampilan proses sains dapat digolongkan menjadi menjadi keterampilan proses dasar dan keterampilan proses terintegrasi, sekalipun komponennya ada yang sama dan ada yang berbeda.
Proses sains dibagi menjadi keterampilan proses yang meliputi: mengamati, mengelompokkan, mengukur, memprediksi, melakukan percobaan, mengkomunikasikan hasil percobaan, dan membuat kesimpulan. Jadi, proses diturunkan dari langkah-langkah yang dilakukan saintis ketika melakukan penelitian ilmiah, langkah-langkah tersebut dinamakan keterampilan proses. Keterampilan proses dapat juga diartikan sebagai kemampuan atau kecakapan untuk melaksanakan suatu tindakan dalam belajar fisika sehingga menghasilkan konsep, teori, prinsip, hukum, maupun fakta atau bukti.

Berdasarkan karakteristik IPA, pembelajaran IPA diarahkan untuk mengajak peserta didik mencari tahu dan berbuat sehingga membantu peserta didik untuk memperoleh pemahaman yang lebih mendalam tentang alam sekitar. Pembelajaran IPA melibatkan peserta didik dalam penyelidikan dengan bimbingan guru. Pembelajaran IPA berorientasi inkuiri, dengan interaksi antara peserta didik dengan guru dan peserta didik lainnya. Peserta didik mengaitkan pengetahuan yang dipelajari dengan 
pengetahuan yang dimilikinya, menerapkan konsep IPA yang dipelajari dengan mengajukan pertanyaan, peserta didik memecahkan permasalahan dengan menggunakan pengetahuan yang dimilikinya, merencanakan dan membuat keputusan, melakukan kegiatan diskusi kelompok, dan memperoleh penilaian yang transparan. Pembelajaran IPA yang berpusat pada peserta didik dan menekankan pentingnya belajar aktif berarti mengubah persepsi tentang guru yang selalu memberikan informasi dan menjadi sumber pengetahuan bagi peserta didik (National Research Council, 1996).

Dalam proses pembelajaran, kecerdasan memegang peranan yang sangat penting. Karena dengan dioptimalkannya kecerdasan yang ada pada diri peserta didik maka akan dapat meningkatkan keaktifan proses belajar peserta didik dan diharapkan memperoleh hasil belajar yang maksimal. Gardner pencetus teori Multiple Intelligences membagi kecerdasan yang ada pada diri seseorang.

Untuk mendukung pembelajaran Multiple Intelligences maka diperlukan model pembelajaran yang sesuai yaitu model pembelajaran inkuiri terbimbing. Karena dengan model pembelajaran inkuiri terbimbing, peserta didik akan mampu mengoptimalkan kecerdasan yang dimilikinya. Kenyataan menunjukkan dalam proses belajar mengajar selalu dijumpai adanya anak yang berbakat, kemampuan tinggi, ada yang kurang berbakat, ada yang cepat ada yang lambat di samping latar belakang mereka yang berupa pengalaman berbeda-beda (Ahmadi dan Supriyono). Oleh sebab itu perlu dibentuk belajar kooperatif agar peserta didik dapat bekerjasama dalam kelompok dan diharapkan dengan kemampuan yang berbeda-beda tersebut, peserta didik yang lebih pintar dapat mengajari peserta didik yang kurang pintar.

Inkuiri terbimbing merupakan cara belajar untuk memenuhi banyak persyaratan kurikulum melalui keterlibatan, memotivasi dan pembelajaran menantang sesuai tujuan abad ke21 di sekolah untuk membimbing peserta didik berpikir dan belajar melalui penyelidikan (Madden, 2011; Kuhlthau, et al., 2007; Zion, et al., 2007). Inkuiri terbimbing ditandai oleh masalah yang di identifikasi dan beberapa pertanyaan oleh guru sebagai prosedur penelitian dan peserta didik diberikan dengan tujuan kinerja peserta didik jelas dan ringkas untuk kegiatan penyelidikan (Wenning, 2011; 2010; 2006; 2005). Penerapan pembelajaran berbasis inkuiri terbimbing tidak hanya dapat meningkatkan kemampuan peserta didik dalam memahami materi tetapi juga dapat meningkatkan kemampuan keterampilan proses sains dan kerja ilmiah (Ambarsari, et al., 2012; Ariesta \& Supartono, 2011; Grant, 2011; Khan,et al., 2011).

\section{METODE PENELITIAN \\ Rancangan Penelitian}

Penelitian ini merupakan penelitian pengembangan yang bertujuan mengungkapkan sejauh mana perangkat pembelajaran IPA model inkuiri terbimbing berbasis multiple intelligences layak digunakan untuk melatihkan keterampilan proses sains peserta didik SMP. Penelitian pengembangan ini mengacu pada model pengembangan Kemp, et al.(2007). Model pengembangan tersebut terdiri atas: 1) Instructional problems; 2) Learner characteristics; 3) Task analysis; 4) Instructional objectives; 5) Content sequencing; 6) Instructional strategies; (7) Instructional delivery; 8) Evaluation instrumens; dan 9) Instructional resources. Perangkat pembelajaran yang dihasilkan meliputi Rencana Pelaksanaan Pembelajaran (RPP), Lembar Kegiatan Peserta didik (LKP), Buku Ajar pada sub bahasan Pemantulan dan cermin, dan instrumen Keterampilan Proses Sains.

Langkah-langkah pengembangan perangkat pembelajaran dengan model inkuiri terbimbing yang diadaptasi dari model pengembangan Kemp yaitu, meliputi: (1) permasalahan dalam pembelajaran dan analisis tujuan, (2) analisis karakteristis peserta didik, (3) analisis data, (4) analisis konsep, (5) menyusun urutan konsep, (6) menyusun urutan konsep, (7) merumuskan tujuan pembelajaran, (8) merancang strategi pembelajaran.

Rancangan penelitian menggunakan rancangan one-group pretest-posttest design. Rancangan penelitian ini melibatkan satu 
kelompok yang diobservasi pada tahap pretest $\left(\mathrm{O}_{1}\right)$ yang kemudian dilanjutkan dengan perlakuan tertentu $(X)$ dan posttest $\left(\mathrm{O}_{2}\right)$.

\section{Subyek Penelitian}

Subyek penelitian adalah peserta didik kelas VIII di SMP Negeri 22 Surabaya semester genap tahun ajaran 2014/2015. Merka terdiri dari 2 kelas, yaitu (1) kelas VIII-1 (30 orang) dan (2) kelas VIII-2 (34 orang). Dalam pelaksanaan pembelajaran kedua kelas sama-sama diberi perlakukan dengan menggunakan bahan ajar model inkuiri terbimbing berbasis multiple intelligences.

\section{Teknik Pengumpulan Data dan pengembangan instrumen}

Teknik pengumpulan data digunakan untuk memperoleh bahan-bahan yang relevan, akurat, dan dapat digunakan dengan tepat sesuai tujuan penelitian. Teknik pengumpulan data yang digunakan dalam penelitian ini adalah: (1) pengamatan; (2) tes; (3) dokumentas; dan (4) angket.

Instrumen penelitian adalah alat yang digunakan untuk mengumpulkan data dalam penelitian. Dalam penelitian ini, instrumen penelitiannya terdiri dari; (1) lembar validasi perangkat pembelajaran (2) Lembar pengamatan keterlaksanaan pembelajaran, (3) instrument penilaian keterampilan proses ains peserta didik, (4) lembar pengamatan sikap peserta didik, (5) angket respon peserta didik, dan (6) lembar catatan kendala-kendala pembelajaran.

\section{Teknik Analisis Data}

Analisis hasil pengembangan perangkat pembelajaran dan hasil ujicoba perangkat pembelajaran IPA yang menggunakan model pembelajaran inkuiri terbimbing dalam penelitian ini meliputi: (1) analisis validasi perangkat pembelajaran meliputi RPP, Buku ajar, LKP, dan instrumen keterampilan proses sains, menggunakan deskriptif kuantitatif kualitatif, dimana data hasil validasi perangkat pembelajaran dianalisis dengan raa-rata skor tiap aspek dan reliabilitasnya. (2) analisis data keterlaksanaan pembelajaran menggunakan deskriptif kuantitatif kualitatif. Nilai dari keterlaksanaan pembelajaran yang dilakukan oleh dua pengamat yang sudah memahami lembar pengamatan secara benar, kemudian data diolah. (3) analisis hasil keterampilan proses sains yang digunakan adalah deskriptif kuantitatif kualitatif. Analisis hasil tes keterampilan proses sains peserta didik pada keterampilan abstrak yaitu data hasil prestest dan posttest dianalisis dengan N-Gain dan setiap butir soal pada keterampilan abstrak dihitung sensitivitas butir soaln, dimana suatu butir soal dikatakan sensiti terhadap pembelajaran apabila $S \geq 0.30$. (4) Lembar pengamatan aspek sikap peserta didik memiliki beberapa aspek yang dinilai berkaitan dengan sikap peserta didik, yaitu spritual, hati-hati, jujur, dan bertanggung jawab. Teknik analisis yang digunakan adalah deskriptif kuantitatif kualitatif, dan (5) Data tentang respon peserta didik diperoleh dari angket respon peserta didik terhadap kegiatan pembelajaran, dan sselanjutnya dianalisis dengan menggunakan deskriptif kuantitaf kualitatif. Data respon yang diperoleh digunakan menindak lanjuti kegiatan pembelajaran IPA model inkuiri terbimbing berbasis multiple intelligences.

\section{HASIL DAN PEMBAHASAN}

Hasil pengembangan perangkat pembelajaran yang meliputi: (1) rencana pelaksanaan pembelajaran, (2) lembar kegiatan peserta didik, (3) buku ajar peserta didik,dan (4) instrumen keterampilan proses sains. Hasil validasi dari pengembangan perangkat pembelajaran adalah sebagai berikut:

Tabel 1. Hasil validasi perangkat pembelajaran

\begin{tabular}{|c|l|c|l|c|}
\hline No & $\begin{array}{l}\text { Perangkat } \\
\text { pembelajaran }\end{array}$ & R & Reliabilitas & K \\
\hline 1 & RPP & 3.51 & $91.80 \%$ & SV \\
\hline 2 & LKP & 3.96 & $92.80 \%$ & SV \\
\hline 3 & Buku Ajar & 3.55 & $97.75 \%$ & V \\
\hline \multirow{2}{*}{4} & \multicolumn{2}{|l|}{ Instrumen KPS } \\
\cline { 2 - 5 } & $\begin{array}{l}\text { Keterampilan } \\
\text { Abstrak }\end{array}$ & 3.4 & $95 \%$ & V \\
\cline { 2 - 5 } & $\begin{array}{l}\text { Keterampilan } \\
\text { Konkrit }\end{array}$ & 4 & $97.14 \%$ & SV \\
\hline
\end{tabular}

Keterangan: R: rata-rata; K: kategori; V: valid;

SV: sangat valid; LKP: lembar kegiatan peserta diidk.

Rencana pelaksanaan pembelajaran (RPP) yang dikembangkan penelitian mengacu pada 
analisis karakteristik peserta didik dan format kurikulum 2013 dengan mempertimbangkan keluasan materi yang disampaikan, maka RPP dibuat dalam 2 kali pertemuan dengan alokasi waktu 2 x 40 menit setiap pertemuannya. Kegiatan pembelajaran yang termuat dalam RPP disesuaikan dengan langkah-langkah yang ada pada model inkuiri terbimbing melalui pembelajaran berbasis inkuiri terbimbing berdasarkan teori multiple intelligences. Pada pengembangan RPP juga dirancang berdasarkan teori multiple intelligences dengan memadukan pada model inkuiri terbimbing yang diharapkan dapat menjadi pembelajaran yang mengintegrasikan aspek sikap spiritual, aspek sosial, keterampilan proses sains sehingga peserta didik memiliki kompetensi IPA yang utuh. Pada RPP juga dikembangkan oleh peneliti pada tahap-tahap untuk melatihkan keterampilan proses sains sesuai dengan pembelajaran berbasis inkuiri terbimbing berdasarkan teori multiple intelligences. Keterampilan proses sains adalah sejumlah proses IPA yang dikembangkan para ilmuan dalam mencari pengetahuan dan kebenaran ilmiah (Kemendikbud, 2014).

Rencana pelaksanaan pembelajaran yang telah dikembangkan peneliti tersebut kemudian divalidasi oleh 2 orang ahli dengan rata-rata skor berdasarkan 3 aspek meliputi: aspek format yang mendapatkan skor 3,5 dengan kategori sangat valid, aspek isi mendapatkan skor 3.7 dengan kategori sangat valid, dan aspek bahasa mendapatkan skor 3.33 dengan kategori valid. Hasil rata-rata validasi RPP dari ketiga aspek adalah 3.51 dan hasil reliabilitas $91.80 \%$ dengan kategori sangat valid (Ratumanan \& Laurens, 2006). Hasil tersebut menunjukkan RPP yang dikembangkan layak digunakan oleh guru dalam pembelajaran

Hasil penilaian secara rata-rata 2 validator ahli terhadap lembar kegiatan peserta didik yang terdiri atas tiga aspek yaitu: 1) aspek format mendapatkan skor 3.75 dengan kategori sangat valid, 2) aspek isi mendapatkan skor 3.5 dengan kategori sangat valid, dan 3) aspek bahasa mendapatkan skor 3.81 dengan kategori sangat valid. Hasil rata-rata validasi LKP dari ketiga aspek adalah 3.69 dan hasil reliabilitas $92.80 \%$ dengan kategori sangat valid (Ratumanan \& Laurens, 2006). Hasil tersebut menunjukkan LKP yang dikembangkan layak digunakan oleh guru dalam pembelajaran.

Buku ajar peserta didik yang dikembangkan berdasarkan beberapa pertimbangan diatas, kemudian divalidasi oleh 2 orang ahli yang meliputi aspek komponen kelayakan isi mendapatkan skor 3.7 dengan kategori sangat valid, aspek komponen bahasa mendapatkan skor 3.35 dengan kategori valid, dan aspek komponen penyajian mendapatkan skor 3.6 dengan kategori sangat valid. Hasil rata-rata validasi buku ajar peserta didik dari ketiga aspek adalah 3.55 dan hasil reliabilitas $97.75 \%$ dengan kategori valid (Ratumanan \& Laurens, 2006). Hasil tersebut menunjukkan buku ajar yang dikembangkan layak dijadikan buku panduan bagi peserta didik maupun guru dalam proses pembelajaran.

Pada keterampilan abstrak Soal yang dikembangkan sebanyak 10 butir soal dengan rincian 2 soal untuk aktivitas verbal (merumuskan masalah dan merumuskan hipotesis), 1 soal untuk menentukan variabelvariabel, 2 soal untuk aktivitas visual (melukiskan bayangan benda pada cermin), 2 soal untuk aktivitas logis-matematis (menganalaisis hasil percobaan), 1 soal. Soal yang telah dikembangkan oleh peneliti divalidasi oleh para ahli secara rata-rata menunjukkan bahwa dari aspek isi perangkat ini mendapatkan skor 3.4 dan reliabilitas hasil $95 \%$ soal tes dinyatakan valid (Ratumanan \& Laurens, 2006). Hasil tersebut menunjukkan tes keterampilan abstrak yang dikembangkan layak dijadikan guru untuk mengukur keterampilan proses sains peserta didik pada sub bahasan pemantulan dan cermin.

Hasil penilaian secara rata-rata 2 validator ahli terhadap lembar instrumen keterampilan konkrit peserta didik yang telah dikembangkan peneliti tersebut divalidasi berdasarkan aspek kelayakan isi, aspek konstruksi, aspek bahasa, dan aspek waktu. mendapatkan rata-rata skor 4 dan reliabilitas hasil $97.14 \%$ dengan kategori sangat valid. (Ratumanan \& Laurens, 2006). Hasil penilaian tersebut menunjukkan bahwa 
lembar pengamatan keterampilan konkrit peserta didik yang telah dikembangkan layak digunakan untuk melakukan menilai keterampilan proses sains peserta didik.

\section{Hasil Uji Coba}

Pada penelitian ini perangkat pembelajaran yang digunakan dalam ujicoba meliputi: (1) keterlaksanaan perangkat pembelajaran, (2) hasil tes keterampilan proses sains peserta didik, (3) Sikap Peserta Didik, dan (4) respon peserta didik. Hasil validasi dari pengembangan perangkat pembelajaran adalah sebagai berikut:

Tabel 2. Hasil validasi perangkat pembelajaran setelah dilakukan uji coba

\begin{tabular}{|c|l|c|c|c|}
\hline No & $\begin{array}{l}\text { Perangkat } \\
\text { Pembelajaran }\end{array}$ & $\begin{array}{c}\text { Rerat } \\
\text { a }\end{array}$ & K & $\begin{array}{c}\text { Reliabili } \\
\text { tas }\end{array}$ \\
\hline \multirow{4}{*}{1} & Keterlaksanaan RPP \\
\cline { 2 - 5 } & Kelas VIII_1 & 3.60 & $\mathrm{~B}$ & $96.76 \%$ \\
\cline { 2 - 4 } & Kelas VIII_2 & 3.50 & $\mathrm{~B}$ & $96.76 \%$ \\
\hline \multirow{5}{*}{2} & Keterampilan Proses Sains \\
\cline { 2 - 4 } & Keterampilan Abstrak & N-gain & Kategori \\
\cline { 2 - 4 } & Kelas VIII_1 & 0.60 & Sedang \\
\cline { 2 - 4 } & Kelas VIII_2 & 0.60 & Sedang \\
\cline { 2 - 4 } & Keterampilan Konkrit & Rerata & Kategori \\
\cline { 2 - 4 } & Kelas VIII_1 & 3.6 & A- \\
\cline { 2 - 5 } & Kelas VIII_2 & 4.0 & A- \\
\hline
\end{tabular}

Perangkat Pembelajaran yang dikembangkan, dan telah ditelaah atau divalidasi oleh ahli, tahap selanjutnya yakni menerapkan. Perangkat Pembelajaran diterapkan untuk mengetahui kepraktisan, dan keefektifannya yang ditinjau dari hasil pengamatan keterlaksanaan rencana pelaksanaan pembelajaran (RPP), keterampilan proses sains.

Hasil analisis keterlaksanaan penggunaan perangkat pembelajaran diamati oleh dua orang pengamat. Pengamatan dilakukan selama 2 kali pertemuan yang merupakan penerapan dari RPP 1, dan RPP 2. Berdasarkan beberapa sintaks pembelajaran yang telah ditulis beberapa pakar, maka sintaks pembelajaran berbasis inkuiri terbimbing berdasarkan teori multiple intelligences yang dikembangkan berdasarkan Branch \& Oberg (2004). Pada RPP terdapat tiga kegiatan yaitu pendahuluan, kegiatan inti, dan kegiatan punutup. Secara keseluruhan dari 2 kelas semua tahap-tahap kegiatan yang ada di dalam RPP pada uji coba 2 terlaksana. Semua tahap-tahap kegiatan yang ada di dalam RPP pada uji coba 2 di kelas VIII_1 terlaksana dan secara rata-rata keseluruhan skor terlaksananya RPP pada pertemuan I adalah 3.51 dengan kategori baik dan rata-rata keseluruhan skor terlaksananya RPP pada pertemuan II adalah 3.70 dengan kategori baik (Ratumanan \& Laurens, 2011). Instrumen keterlaksanaan RPP pada pertemuan I mempunyai rata-rata reliabilitas adalah $97.50 \%$ dengan berkategori baik dan Instrumen keterlaksanaan RPP pada pertemuan II mempunyai rata-rata reliabilitas adalah 96.02\% dengan berkategori baik (Borich, 1994). Sedangkan tahap-tahap kegiatan yang ada di dalam RPP pada uji coba 2 di kelas VIII_2 terlaksana dan secara rata-rata keseluruhan skor terlaksananya RPP pada pertemuan I adalah 3.5 dengan kategori baik dan rata-rata keseluruhan skor terlaksananya RPP pada pertemuan II adalah 3.51 dengan kategori baik (Ratumanan \& Laurens, 2011). Instrumen keterlaksanaan RPP pada pertemuan I mempunyai rata-rata reliabilitas adalah $96.02 \%$ dengan berkategori baik dan Instrumen keterlaksanaan RPP pada pertemuan II mempunyai rata-rata reliabilitas adalah 97.5\% dengan berkategori baik (Borich, 1994).

Nilai pretest digunakan untuk mengetahui keterampilan abstrak awal peserta didik. Nilai posttest yang diperoleh peserta didik menggambarkan tentang keterampilan abstrak peserta didik setelah mengikuti pembelajaran berbasis inkuiri terbimbing berdasarkan teori multiple intelligences. Hasil uji coba 2 pada kelas VIII_1 penerapan hasil pengembangan perangkat pembelajaran berbasis inkuiri terbimbing berdasarkan teori multiple intelligences dapat melatihkan keterampilan abstrak peserta didik diperoleh bahwa n-gain rata-rata adalah 0.60\% dengan kategori sedang (Hake, 1999). Sedangkan hasil pengamatan keterampilan konkrit peserta didik pada pembelajaran berbasis inkuiri terbimbing berdasarkan teori multiple intelligences pada uji coba 2 pada kelas VIII_1 didapat bahwa rata-rata penilaian pengamatan keterampilan konkrit pada 30 peserta didik adalah 3.6 dengan kategori A- (Hake, 1999).

Hasil tes keterampilan abstrak pada uji coba 2 pada 34 peserta didik di kelas VIII_2 diperoleh 
bahwa penerapan hasil pengembangan perangkat pembelajaran berbasis inkuiri terbimbing berdasarkan teori multiple intelligences dapat melatihkan keterampilan kognitif peserta didik dengan n-gain rata-rata adalah $0.60 \%$ dengan kategori sedang (Hake, 1999). Sedangkan hasil pengamatan keetrampilan konkrit peserta didik pada pembelajaran berbasis inkuiri terbimbing berdasarkan teori multiple intelligences pada uji coba 2 Kelas VIII_2 didapat bahwa rata-rata penilaian pengamatan keterampilan konkrit pada 34 peserta didik adalah 4.0 dengan kategori A- (Hake, 1999).

Peningkatan yang ditunjukkan oleh hasil analisis dengan menggunakan n-gain menunjukkan tentang penerapan dari pengembangan perangkat pembelajaran IPA berbasis inkuiri terbimbing berdasarkan teori multiple intelligences efektif dalam melatihkan keterampilan abstrak pada sub bahasan pemantulan dan cermin. Respon peserta didik merespon sangat kuat terhadap keterampilan abstrak. Hasil diperkuat dengan hasil penelitian Maliyah (2012), Astuti (2013), dan David (2006) yang menyatakan bahwa pembelajaran dengan menggunakan proses pembelajaran berbasis inkuiri terbimbing berdasarkan teori multiple intelligences dapat melatihkan keterampilan kognitif peserta didik. Sedangkan pada pengamatan terhadap keterampilan konkrit yang dinilai dalam penelitian ini adalah menyusun alat dan bahan, menggunakan alat dan bahan pada eksperimen, mengukur jarak benda, mengukur jarak bayangan benda, dan melukis bayangan benda.

Peningkatan yang ditunjukkan oleh hasil analisis pada keterampilan konkrit menunjukkan tentang penerapan dari pengembangan perangkat pembelajaran IPA berbasis inkuiri terbimbing berdasarkan teori multiple intelligences efektif dalam melatihkan keterampilan proses sains pada keterampilan konkrit peserta didik pada sub bahasan pemantulan dan cermin. Dalam proses pembelajaran, kecerdasan memegang peranan yang sangat penting. Karena dengan dioptimalkannya kecerdasan yang ada pada diri peserta didik maka akan dapat meningkatkan keaktifan proses belajar peserta didik dan diharapkan memperoleh hasil belajar yang maksimal. Hal ini menunjukkan bahwa pembelajaran berbasis inkuiri terbimbing berdasarkan teori multiple intelligences dapat menjadi sarana guru untuk dapat menyesuaikan pengalaman belajar, sumber daya, kebutuhan yang disesuaikan dengan kemampuan masingmasing peserta didik.

Pada penilitian ini, penilaian kompetensi sikap dilakukan dengan observasi (pengamatan) oleh dua orang pengamat menggunakan lembar observasi sikap. Indikator sikap spiritual pada penelitian ini yakni, peserta didik dapat memberi contoh peristiwa yang teratur dan kompleks dimana manusia tidak dapat menciptakan kecuali Tuhan. Aspek sikap sosial yang diamati meliputi hati-hati, tanggung jawab, dan jujur. Berdasarkan data hasil belajar aspek sikap diperoleh bahwa sikap peserta didik semuanya berkategori baik. Hal ini menunjukkan bahwa kompetensi sikap peserta didik yang teramati dapat dikembangkan.

Hasil pengamatan pada aspek sikap ini menunjukkan bahwa pembelajaran berbasis inkuiri terbimbing berdasarkan teori multiple intelligences dapat memunculkan sikap sosial yakni hati-hati, peserta didik dalam menggunakan alat dan bahan selama pelaksanaan percobaan selalu berhati-hati; sikap jujur, peserta didik mencatat data dan merumuskan kesimpulan sesuai dengan data hasil pengamatan percobaan, tidak mencontek jawaban orang lain; sikap tanggung jawab, peserta didik mengembalikan ala-alat percobaan dan membuat laporan hasil percobaan. Hal ini senada dengan apa yang disampaikan oleh Kuhlthau dan Klentschy yang menyatakan bahwa inkuiri terbimbing dirancang untuk membimbing peserta didik dalam proses berpikir, membangun pengetahuan, meningkatkan minat dan penyelidikan untuk mendapatkan pengetahuan dan pemahaman mendalam, bertahap pada belajar mandiri.

Berdasarkan hasil analisis respon peserta didik terhadap pengembangan perangkat pembelajaran (yang meliputi: buku ajar peserta didik dan lembar kegiatan peserta didik) pada dua kelas diperoleh bahwa pelaksanaan 
pembelajaran berbasis inkuiri terbimbing berdasarkan teori multiple intelligences pada kelas VIII_1 pada 30 peserta didik didapatkan hasil bahwa sebanyak $79.2 \%$ peserta didik menyatakan senang, $82.00 \%$ peserta didik menyatakan bahwa pembelajaran IPA berbasis inkuiri terbimbing berdasarkan teori multiple intelligences baru dilaksanakan dalam pembelajaran, $74.6 \%$ peserta didik menyatakan bahwa pembelajaran IPA berbasis inkuiri terbimbing berdasarkan teori multiple intelligences sangat membatu peserta didik dalam mempalajari IPA khususnya sub bahasan pemantulan dan cermin, $74.7 \%$ peserta didik menyatakan bahwa bimbingan guru dalam pembelajaran sudah sesuai dengan aktivitasaktivitas kecerdasan peserta didik.

Respon peserta didik terhadap latihan-latihan yang diberikan selama pembelajaran sudah sesuai dengan aktivitas-aktivtas peserta didik adalah $95.4 \%$ dan menyatakan sangat senang melakukan kegiatan-kegiatan yang diberikan meskipun masih ada kekurangan-kekurangan di dalamnya. Serta peserta didik menyatakan bahwa pembelajaran yang melatih peserta didik dalam keterampilan proses sains sangat baru dilaksanakan selama proses pembelajaran, sehingga selama prosesnya peserta didik sangat butuh bimbingan dari guru.

Pelaksanaan pembelajaran berbasis inkuiri terbimbing berdasarkan teori multiple intelligences pada kelas VIII_2 pada 34 peserta didik didapatkan hasil bahwa sebanyak $80.0 \%$ peserta didik menyatakan senang, $82.00 \%$ peserta didik menyatakan bahwa pembelajaran IPA berbasis inkuiri terbimbing berdasarkan teori multiple intelligences baru dilaksanakan dalam pembelajaran, $78.6 \%$ peserta didik menyatakan bahwa pembelajaran IPA berbasis inkuiri terbimbing berdasarkan teori multiple intelligences sangat membatu peserta didik dalam mempalajari IPA khususnya sub bahasan pemantulan dan cermin, $74.7 \%$ peserta didik menyatakan bahwa bimbingan guru dalam pembelajaran sudah sesuai dengan aktivitasaktivitas kecerdasan peserta didik.

Respon peserta didik terhadap latihan-latihan yang diberikan selama pembelajaran sudah sesuai dengan aktivitas-aktivtas peserta didik adalah $85.4 \%$ dan menyatakan sangat senang melakukan kegiatan-kegiatan yang diberikan meskipun masih ada kekurangan-kekurangan di dalamnya. Serta peserta didik menyatakan bahwa pembelajaran yang melatih peserta didik dalam keterampilan proses sains sangat baru dilaksanakan selama proses pembelajaran, sehingga selama prosesnya peserta didik sangat butuh bimbingan dari guru.

Berdasarkan hasil analisis dapat diketahui bahwa respon peserta didik terhadap pengembangan perangkat dan pelaksanaan pembelajaran selama uji coba 2 adalah positif dengan kategori sangat kuat. Hal ini berarti peserta didik mendukung, merasa senang, dan berminat terhadap pembelajaran dengan menggunakan perangkat hasil pengembangan model inkuiri terbimbing untuk melatihkan keterampilan proses sains. Hasil ini sesuai dengan hasil penelitian dari Wahyudi (2013) yang menyatakan bahwa dengan menggunakan model inkuiri terbimbing untuk melatihkan keterampilan proses sains dapat meningkatkan hasil belajar dan mendapatkan respon postif dari peserta didik.

\section{PENUTUP}

Berdasarkan analisis data penelitian dan pembahasan diperoleh hasil bahwa perangkat pembelajaran IPA model inkuiri terbimbing berbasis multiple intelligences pada sub bahasan pemantulan dan cermin yang dikembangkan memenuhi syarat validitas, kepraktisan, dan efektivitas sehingga layak digunakan untuk melatihkan keterampilan proses sains.

\section{DAFTAR PUSTAKA}

Ambarsari, W. Santosa,S. danMaridi.(2012). "Penerapan pembelajaran inkuiri terbimbing terhadap ketrampilanproses sains dasar pada pelajaran biologi siswa kelas VIII SMP Negeri 7 Surakarta”. Jurnal pendidikan biologi Universitas Sebelas Maret.Vol.5 No. 1, pp. 81-95.

Ariesta, R. dan Supartono. (2011). "Pengembangan perangkat perkuliahan kegiatan laboratorium fisika dasar II 
berbasis inkuiri terbimbing untuk meningkatkan kerja ilmiah mahasiswa”. Jurnal pendidikan fisika indonesia (JPFI). No.1 Vol.7, pp. 62-68.

Borich, G.(1994). Observation skill for effective teaching. New York: Mac Millan Publishing Company.

Branch, J. and Oberg, D. (2004). Focus on inquiry a teacher guide to implementing inquiry based learning. Canada: Alberta Education, Alberta.

David, M. H. (2006). Instructor's guide to processoriented guided-inquiry learning. SUNY:Stony Brook University.

Depdiknas. (2006). Model Pembelajaran Terpadu IPA. Jakarta: Depdiknas.

Grant, H. (2011). "The student experience in traditional and inquiry based chemistry labs". (PDF). Retrieved April 30, (2014) from Montana State University Library.

Hake. (1999). Analyzing Change/Gain Scores. (Online).

Tersedia http://www.physicsindiana.edu/sdi/Analyzi $\underline{\text { ng-Change-Gain.pd. Diakses } 13 \text { Februari }}$ $\underline{2015}$.

Kemendikbud. (2014). Buku guru Ilmu Pengetahuan Alam SMP/MTS Kelas VIII. Jakarta: Pusat Kurikulum Dan Perbukuan, Balitbang, Kemdikbud.

Kemp, J.E.and Morison. (2007). Designing effective instruction. New York: Macmillan College Publishing Company.

Kuhlthau, C.C. (2010). "Guided inquiry".School libraries worldwide. Vol.16 No. 1, pp. 17-28.

Madden, K. (2011). "The use of inquiry-based instruction to increase motivation and academic success in a high school biology classroom”.(PDF). Retrieved April 30, (2014) from Montana State University library.

Maliyah, N. dkk. (2012). "Pembelajaran fisika dengan inkuiriter bombing melalui metode eksperimen dan demontrasi diskusi ditinjau dari kemampuan matematik dan kemampuan verbal siswa".Jurnal Inkuiri. Vol.1 No.3, pp.227-234.
National Research Council. (2001). Inquiry and the national science education standards. Washington, DC: National Academy Press.

Wenning, C. J. (2011). "Experimental inquiry in introductory physics courses" JPTEO (Journal of Physics Teacher Education Online) Illinois State University Physics Dept. USA.Vol.6No.2,pp. 7.

Zubaidah, S., Mahanal, S, dan Yuliati, L. $2013 a$. Ragam Model Pembelajaran IPA

SMP. Malang: Universitas Negeri Malang.

Zubaidah, S., Mahanal, S, dan Yuliati, L. 2013b. Ragam Model Pembelajaran IPA SMP. Malang: Universitas Negeri Malang.

Khan, M. S. Hussain, A.R. Majoka, M. I. andRamzan, M.(2011)."Effect of inquiry method on achievement of students in chemistry at secondary level". International journal of academic research. Vol.3 No.1, pp. 955-959.

Ratumanan, G.T. dan Laurens. (2006). Evaluasi hasil yang relevan dengan memecahkan problematika belajar dan mengajar. Bandung:CV Alfabeta. 